Saudi Journal of Humanities and Social Sciences

Abbreviated Key Title: Saudi J Humanities Soc Sci

ISSN 2415-6256 (Print) | ISSN 2415-6248 (Online)

Scholars Middle East Publishers, Dubai, United Arab Emirates

Journal homepage: https://saudijournals.com

Original Research Article

\title{
Internalization of Prophetical Values in Generating Teachers' Competences
} Suprihatini $^{1 *}$, Masyitoh $^{1}$, Gofur Ahmad $^{1}$, Diah Mutiara ${ }^{1}$

${ }^{1}$ University Muhammadiyah, Jakarta, Indonesia

DOI: $\underline{10.36348 / \text { sjhss.2022.v07i01.005 }}$ | Received: 04.12.2021 | Accepted: 06.01.2022 | Published: 19.01.2022

*Corresponding author: Suprihatini

University Muhammadiyah, Jakarta, Indonesia

\section{Abstract}

The concentration of this study is to analyze: (1) the academic basis of Madrasa Miftahul Umam in generating teachers' competences through vision mission; (2) the role of teachers in dealing with obstacles to generate teachers' competences; (3) the role of internalizing prophetic values in generating teachers' competences to create more effective teaching and learning activities. The research in the paper uses the case study method. Data collection was carried out through interviews, observations, document reviews, and surveys to complement the data. Sources of data were obtained through teachers as informants and also through documents. Data analysis was performed by data reduction or sorting, data displays and verifications. The results of the study show that: (1) generating teachers' competence had been carried out through the madrasa vision and mission, but its implementation had not been well-programmed; (2) various obstacles faced by madrasa such as financial sector, quality of management, facilities and infrastructure, had a direct impact towards generating teachers' competences; (3) internalization of prophetic values on teachers competence was able to motivate teachers to build teachers' values and to create more effective teaching and learning activities. The Conclusion in this study proves that the internalization of prophetic values had positively impacted towards generating teachers' competences.

Keywords: Effective teaching and learning process, generating of competences, internalization of prophetical values, teachers' Competences, teachers' values.

Copyright (C) 2022 The Author(s): This is an open-access article distributed under the terms of the Creative Commons Attribution 4.0 International License (CC BY-NC 4.0) which permits unrestricted use, distribution, and reproduction in any medium for non-commercial use provided the original author and source are credited.

\section{INTRODUCTION}

Religion is here to be a solution to various problems that start from the root cause, namely the issue of faith, mindset, and perception of problems that occur in society, such as social, economic, political, legal, cultural, environmental issues, and of course educational problems (Abuddin Nata, 2014: 8). This is because religious teachings are believed to contain basic principles concerning all aspects of life, and contain wisdom that serves to guide the way of human life (M. Ma'ruf, 2015: 20). Then the religious package in Islamic education are considered capable of producing a cultural process to increase dignity in the family, school, and community environment (Samrin, 2015: 103). This means, education that carries the values of religious teachings is able to support social and moral improvement, as well as making a very convincing contribution to life and social arrangement (Aris Saefulloh, 2008: 166).

The importance of education as stated by Abuddin Nata, Ma'ruf, Samrin and Aris above, because education has very important role in building the arrangement of nation and the state, especially in developing required human resources. And as proposed by Darwyan Syah et al., education is considered as a core tool for learning process to develop the quality of graduates as quality human resources, in an effort to encourage the development of the economic sector and other interrelated sectors simultaneously (Darwyan Syah, 2006: 1). Therefore, as said by Sanusi $e t$ al it has an important role as a development dynamist (Sanusi Uwes, 2017: 27). As a consequence, the essence of educational development has to be in line with national ideals of Republic Indonesia, namely the ideals of educating nation's life, promoting general welfare, and social justice. Therefore, so that education can be implemented effectively and in accordance with the ideals of the nation through national development, its implementation must be based on the Law of the Republic of Indonesia Number 20 of 2003 concerning the National Education System (Sisdiknas) 
Suprihatini et al; Saudi J. Humanities Soc Sci, Jan, 2022; 7(1): 29-38

To actualize the national education goals, madrasa as an executor unit of the education has a very strategic role. According to Sujana, madrasa has to be developed as a conducive pedagogical social order and provides an atmosphere for the growth and development of various personal qualities of students. Madrasa as an integral part of the society, needs to be managed as a center for cultivating and empowering the students for life who are able to set an example, build willingness, and develop students' creativity in democratic learning (I Wayan Cong Sujana, 2019: 33). Therefore, as mentioned by the Law of the Republic of Indonesia Number 20 of 2003 concerning the National Education System, Chapter XIV, Article 51, paragraph 1 , the effectiveness of madrasa management must have operational standards, and by according to the law which is stated that the madrasa management of early childhood education, basic education and secondary education units is carried out based on minimum service standards with madrasa-based management (MBM). In this case, technically Nur et al strengthens that MBM can be interpreted as everything related to the management of educational process to achieve the goals that have been set for short-term, medium and long-term goals. MBM operational activities to improve the quality of education include: (1) madrasa planning program; (2) implementation of madrasa planning: (3) and overcoming madrasa obstacles (Muhammad Nur, 2016: 93).

However, madrasas in Indonesia which are dominated by private madrasas, have not been able to escape from the obstacles they face. Especially those related to managerial skills and financial constraints that have impact on the operationalization of madrasas, and in particular on teachers' competences. According to Ibrahim (2015) that one the obstacles in the implementation of $\mathrm{MBM}$ is the lack of adequate funding needs (Ibrahim, 2015: 124). Thus, educational leadership through MBM should no longer be trapped in a deadlock solution, but must optimize the various existing resources, especially educator resources as the spearhead of MBM, namely by maximizing teachers' competencies improvement to manage it into a challenge. That is, any changes that occur to the education system can be faced by the MBM leadership, and teachers become something more useful for madrasa, students and community (Abdul Hadi, 2013: 144). This is in line with the problem solving efforts by the World Bank, where one of the World Bank's important recommendations is to focus on handling effective learning processes (Ari Hasan Anshori, 2016: 25).

The importance of generating teachers' competences because the main problem is the strategic role of teachers still not being able to create quality education, so they can not compete. According to Mainuddin, teachers' competences are considered important not only as a selection tool in the recruitment of prospective teachers, but also as a guidance and development of the current teachers. Competences are the most important teachers' qualifications. If the teachers are not competent, they will not be able to carry out teaching tasks and to create quality outcomes (Mainuddin, 2017: 3).

By understanding the above phenomenon, the World Bank's recommendation to create an effective learning process is very realistic, considering that educational institutions have never had a shortage of educators. Moreover, educators are the spearhead of the learning process. This means that the role of educators in the most important element in the limitations of infrastructure in an educational institution of developing countries, including in Indonesia (Dwi Esti Andriani, 2012: 395). Therefore, generating teachers' competences is very crucial. Evaluation of teachers in carrying out their roles mst be balanced with the efforts of madrasa leader who encourage the important role of teachers in carrying out the duties. This mean that madrasa management must respond with serious efforts in various madrasa management units. But the main mission of generating teachers' competences, as stated by Dunlosky (2013) is an effort to find solutions to help students and lead them towards effective learning techniques (John Dunlosky et al., 2013: 4). With another understanding, the generating of teachers' competences must be based in innovations that are able to create a cheap, optimal, effective and efficient learning process.

Thus, it is better for the leader of madrasa to make their operations basis in accordance with the law of national education goals. That is based on religious values, Indonesian national culture, and responsiveness to the demands of changing times. The contents of the law above provide space for madrasa to carry out various innovations. The goal of national educations which are based on religious values has the power to motivate the teachers' roles in a prophetic view. However, prophetic values have dogmatic power so that teachers as creators have the responsibility to fulfill the obligations of God's commands as educators. According to Ridwan et al, religion basically brings a number of rules in the form of law (norms) that must be implemented by its adherents as an attitude of submission and obedience to God. So that those who carry out God's law will get a good reward, as well as those who deny it will get a bad reply (MK Ridwan et al, 2016: 157). By analyzing the various discussion above, this study assumes that generating teachers' competences with a prophetic approach is a step that is considered appropriate to actualize of teachers' competences who are able to produce a harmonious and effective learning process. Hoped this research will implicate towards useful and effective study. 
Suprihatini et al; Saudi J. Humanities Soc Sci, Jan, 2022; 7(1): 29-38

\section{PURPOSE OF THE STUDY}

Based on the above mentioned backgrounds, this study was intended to fulfill the following purposes:

The concentration of this study is to analyze: (1) the academic basis in generating the competences of teachers of Madrasa Miftahul Umam in South Jakarta; (2) the role of teachers in dealing with obstacles to generating teachers' competences at the Madrasa Miftahul Umam; (3) the role of internalizing prophetic values in generating teachers' competences in order to be able to create more effective teaching and learning activities.

a) To analyze how far the management of Madrasa Miftahum Umam is able to generate the competences of the teachers through its vision and mission.

b) To analyze how far the teachers of Madrasa Miftahul Umam are able to face the obstacles and to motivate themselves in generating the competences.

c) To analyze to what extent that internalization of prophetical values is able to generate the competences of teachers towards educational insights, morals and integrity to produce an effective learning and teaching practice.

\section{RESEARCH METHOD}

\subsection{Location of the Study}

In this paper, Madrasa Tsanawiyah Miftahul Umam was chosen to be the locus of the research, as it is predicted to be able to reflect the discourse of this study and to consider to these following reasons: (1) Madrasa Miftahul Umam is an Islamic tertiary institution which is having problems in one side, and is developing its quality in another side; (2) Madrasa Miftahul Umam is an educational institution where some teaching material consists of various religiousbased disciplines and according to its vision and mission. Therefore, the model of the learning and teaching process reflects the religious-based social interaction system; (3) Madrasa Miftahul Umam has majority teachers who have religious educational background and with their spiritual quality, teachers are more able and easily to understand and implement the prophetic-based competences in learning and teaching process.

\subsection{Subject}

In this study, the primary data collected from Madrasa Miftahul Umam was resulted by interview with teachers as informants. The subjects are about (a) the performance and problems faced by management of Madrasa Tsanawiyah Miftahul Umam as well as by teachers; (b) teachers' perceptions towards academic teachers' competences as well as internalization of prophetical values in influencing teachers' performances. Ten teachers as informants were randomly selected to become primary data sources. However, the data collected was saturated with the six informants. Those six informants are able to understand the content of Al-Qur'an. The secondary data was taken from observations as well as documents to support primary data collected.

\subsection{Procedure}

Those two verbatims above were taken by face-to-face interviews for about 30 minutes for each informant. Madrasa documents related to the performance of Madrasa Tsanawiyah Miftahul Umam as well as teachers' perceptions in competences as well as prophetical understanding related to academic competences were collected and analyzed. All data collected from both of resources are to be displayed and gathered integrally to build up comprehensive rapport and to support the phenomenon and ensure those data are able to explain the objectives of the research.

\section{RESULT OF THE STUDY}

\subsection{Madrasa Management Role in generating Teachers' Competences Through Visions and Missions}

The vision and mission of educational institution in Indonesia has to be in line with national education goals, that is a part of the national education system which is based on national principle called Pancasila and constitution called Undang-Undang Dasar Republic of Indonesia 1945. And as mentioned in The Indonesian Republic Law concerning National Education System, Chapter I, Paragraph 1, the main content is rooted in religious values, Indonesian national culture, and responsive to the demands of the new era. And as mentioned in the Indonesian Republic Law concerning Higher Education, Chapter I, Article 5, Paragraph a, the objectives points to be elaborated into more technical policies, that students have to be potentially developed into human being who believe and fear God almighty and have to be noble, healthy, knowledgeable, capable, creative, independent, competent and cultured interest nation. In this case, the vision and mission of foundation as well as institution of Madrasa Miftahul Umam are designed as below tables: 
Table-1: Vision and Mission of Miftahul Umam Foundation

\begin{tabular}{|l|l|}
\hline Vision & $\begin{array}{l}\text { To become a leading and modern Islamic educational institution in enlightening and educating the nation's } \\
\text { life to form an Indonesian society that is faithful, knowledgeable, charitable, pious, and masters } \\
\text { technology towards superior people. }\end{array}$ \\
\hline Mission & $\begin{array}{l}\text { (a) To manage the quality of Islamic education activities through formal and non-formal institutions to } \\
\text { produce healthy, intelligent and independent students and master science and technology; } \\
\text { (b) To uphold educational values in accordance with the Islamic curriculum and teachings in order to form } \\
\text { a reliable and intelligent generation; } \\
\text { (c) To improve the quality of human resources in order to create a society of faith, knowledgeable, and } \\
\text { charity, and piety as well as improve the scienc and technology; } \\
\text { (d) To encourage the realization of national unity and integrity to chieve the welafare of all Indonesial } \\
\text { people. }\end{array}$ \\
\hline
\end{tabular}

Source: Internal document of Mistahul Umam Foundation - access in August, 2021

Table-2: Vision and Mission of Madrasa Miftahul Umam

\begin{tabular}{|l|l|}
\hline Vision & $\begin{array}{l}\text { To actualize that graduates are able to become figures of strong faith and knowledge of benefits and } \\
\text { have advantages of science and technology. }\end{array}$ \\
\hline Mission & $\begin{array}{l}\text { (a) To create an effective, creative and fun learning system; } \\
\text { (b) To encourage and help students to recognize and explore their potential so that they are able to } \\
\text { develop optimally; } \\
\text { (c) To provide motivation and foster the spirit towards appreciation and practice the teachings of Islam; } \\
\text { (d) To improve the strategy of teaching and learning activities, so that high national exam scores are } \\
\text { obtained; } \\
\text { (e) To encourage students to master science and have strong faith and piety. }\end{array}$ \\
\hline
\end{tabular}

Related to both foundation and madrasa's visions and missions, 6 teachers as informants are interviewed to know how far that the teachers comprehend the points, involve to design and to review periodically and utilize them as guidances to generate the competences and to produce the knowledge and sills and are able to manage the class to become effectively learning and teaching activities. The following points in the table- 3 below are the perceptions of the teachers as descprited above:

Table-3: Teachers' Perceptions to Both Foundation and Madrasa's Vision and Mission

\begin{tabular}{|l|l|}
\hline Subject & Perceptions \\
\hline $\begin{array}{l}\text { Vision and Mission } \\
\text { of Foundation and }\end{array}$ & $\begin{array}{l}\text { (a) The teachers know that foundation and madrasa have own visions and missions and } \\
\text { displayed in the office only - and not in several strategic places for socializing purposes; } \\
\text { (b) The teachers are not involved and even asked for opinion in designing the vision and } \\
\text { mission for both foundation and madrasa; } \\
\text { (c) The teachers have never received an emphasis on the meaning, understanding, goals, and } \\
\text { also the technical implementation of the vision and mission of foundation and madrasa; } \\
\text { (d) The teachers had never been supervised and evaluated in implementing the activities } \\
\text { which are related closely to the vision and mission; } \\
\text { (e) Teachers do not realize the the vision and mission should be used as the operational basis } \\
\text { for madrasa and become a guidance for teachers to carry out their professional duties. } \\
\text { (f) Teachers are not well managed to realize that vision and mission is the main media in } \\
\text { generating teahers' competences. } \\
\text { (g) The teachers are less given an understanding that the vision and mission are the main } \\
\text { devices of achieving madrasa's goals. }\end{array}$ \\
\hline
\end{tabular}

4.2 Teachers Role in facing the obstacles and motivating themselves to generate the competences

Below table is the list of some the obstacles that currently occur to madrasa management of
Miftahul Umam which content for various phenomenons. Those obstacles are according to the facts and findings reported by teachers as informants: 
Suprihatini et al; Saudi J. Humanities Soc Sci, Jan, 2022; 7(1): 29-38

Table 4: Some Obstacles in Madrasa Miftahul Umam Related to Teachers Competences

\begin{tabular}{|l|l|l|l|l|l|}
\hline No. & $\begin{array}{l}\text { Supporting } \\
\text { Facilities }\end{array}$ & Obstacles & Implication & $\begin{array}{l}\text { Teachers' } \\
\text { Responds/Actions }\end{array}$ \\
\hline 1. & $\begin{array}{l}\text { Overhead } \\
\text { Projector }\end{array}$ & $\begin{array}{l}\text { Some in-focus projectors are } \\
\text { malfunctions and even in some } \\
\text { class-rooms are not provided } \\
\text { yet }\end{array}$ & $\begin{array}{l}\text { 1) } \\
\text { Learning material to be delivered } \\
\text { manually and it takes time to finish. } \\
\text { Learning materials are ineffectively } \\
\text { delivered as it is not up to complete } \\
\text { schedule }\end{array}$ & $\begin{array}{l}\text { 1) } \\
\text { Sometimes feel } \\
\text { frustrated } \\
\text { To deliver certain } \\
\text { important learning } \\
\text { material }\end{array}$ \\
\hline 2. & Computer & $\begin{array}{l}\text { Most of teachers do not have } \\
\text { personal computers and } \\
\text { madrasa does not provide } \\
\text { computer in the classroom yet }\end{array}$ & $\begin{array}{l}\text { 1) } \\
\text { Learning material to be delivered } \\
\text { manually and it takes time to finish. } \\
\text { Learning materials are ineffectively } \\
\text { delivered as it is not up to complete } \\
\text { schedule }\end{array}$ & $\begin{array}{l}\text { 3) } \\
\text { Sometimes feel } \\
\text { frustrated } \\
\text { To deliver certain } \\
\text { important learning } \\
\text { material }\end{array}$ \\
\hline 3. & $\begin{array}{l}\text { Training } \\
\text { Program }\end{array}$ & $\begin{array}{l}\text { Training programs to generate } \\
\text { teachers' competences are not } \\
\text { scheduled consistently }\end{array}$ & $\begin{array}{l}\text { Teachers do not have opportunities to develop } \\
\text { own competences properly }\end{array}$ & $\begin{array}{l}\text { Teachers need to seek } \\
\text { own programs to develop }\end{array}$ \\
\hline 4. & $\begin{array}{l}\text { CCTV } \\
\text { Installation }\end{array}$ & $\begin{array}{l}\text { The budget is too high but it is } \\
\text { not a need-based priority }\end{array}$ & $\begin{array}{l}\text { Teachers feel a priori and disappointed with the } \\
\text { program }\end{array}$ & Do the job and ignorant \\
\hline
\end{tabular}

The obstacles as listed in the table 4 above might implicate to the academic performances of teachers in generating competences. Therefore, the table 5 below is the list of teachers' performances in term of competences which are affected by obstacles listed in the table 4:

Table 5: Academic Performances on Teachers' Competences

\begin{tabular}{|l|l|l|l|}
\hline No. & Competences & Teachers' Statements & Percentage of Performances \\
\hline 1. & $\begin{array}{l}\text { Pedagogical } \\
\text { Competences }\end{array}$ & $\begin{array}{l}\text { All teachers are not able to mention and understand the } \\
\text { elements of pedagogical competences completely }\end{array}$ & $65 \%$ \\
\hline 2. & $\begin{array}{l}\text { Personal } \\
\text { Competences }\end{array}$ & $\begin{array}{l}\text { All teachers are not able to mention and understand the } \\
\text { elements of personal competences completely }\end{array}$ & $75 \%$ \\
\hline 3. & $\begin{array}{l}\text { Social } \\
\text { Competences }\end{array}$ & $\begin{array}{l}\text { All teachers are not able to mention and understand the } \\
\text { elements of social competences completely }\end{array}$ & $60 \%$ \\
\hline 4. & $\begin{array}{l}\text { Professional } \\
\text { Competencies }\end{array}$ & $\begin{array}{l}\text { All teachers are not able to mention and understand the } \\
\text { elements of professional competences completely }\end{array}$ & $65 \%$ \\
\hline Average & $\begin{array}{l}\text { All } \\
\text { Competences }\end{array}$ & $\begin{array}{l}\text { All teachers are not able to mention and understand the } \\
\text { elements of all competences }\end{array}$ & $66.25 \%$ \\
\hline
\end{tabular}

Within the obstacles faced by madrasa as well as poor performances of teachers' competences, teachers need to seek the way to find solutions in generating competences. Below are the list of programs managed by outside training organizations which are expected by teachers to be able to develop their individual academic competences:

Table 6: Program-Program Peningkatan Kompetensi Guru

\begin{tabular}{|c|c|c|c|c|}
\hline No. & Name of Training/Seminar & Organizer & Year & Competency \\
\hline 1. & Introduction Expressive Arts Therapy & Edupotensia Counseling Bureu & 2021 & Professional \\
\hline 2. & $\begin{array}{l}\text { Practice Inspiration of Evaluating in Online } \\
\text { Learning Results }\end{array}$ & Yasmin Learning Center & 2021 & Pedagogic \\
\hline 3. & Resolution 2021 Towards Digital Madrasah & South Jakarta Ministry of Religion Office & 2021 & Pedagogic \\
\hline 4. & $\begin{array}{l}\text { Freedom to learn basic education in the national } \\
\text { digital literacy movement }\end{array}$ & University of Maarif Hasyim Latif Sidoarjo & 2021 & Pedagogic \\
\hline 5. & $\begin{array}{l}\text { Commitment to build Indonesian Education in } \\
\text { future }\end{array}$ & $\begin{array}{l}\text { Indonesian Teachers Association and } \\
\text { University of STEKOM }\end{array}$ & 2021 & Pedagogic \\
\hline 6. & Fun Madrasa Movement & Erlangga Press & 2021 & Social \\
\hline 7. & $\begin{array}{l}\text { Opportunity and Challenge of Islamic Education } \\
\text { in } 4.0 \text { Industry Revolution Era }\end{array}$ & South Jakarta Ministry of Religion Office & 2019 & Pedagogic \\
\hline 8. & Fun of Full Day School & Postgraduate school of UHAMKA & 2017 & $\begin{array}{l}\text { Pedagogic } \\
\text { an social }\end{array}$ \\
\hline 9. & $\begin{array}{l}\text { To Strengthen Islamic Educational Management } \\
\text { in facing educational globalization }\end{array}$ & University of Muhammadiyah Jakarta & 2016 & Pedagogic \\
\hline 10. & Scientific Solution to Global Crisis & University of Muhammadiyah Jakarta & 2016 & Professional \\
\hline 11. & Implementation of curriculum 2013 workshop & Yayasan Miftahul Umam Foundation & 2016 & Pedagogic \\
\hline
\end{tabular}

Source: Formal Document of Madrasah Tsanawiyah Miftahul Umam - 2021 
Suprihatini et al; Saudi J. Humanities Soc Sci, Jan, 2022; 7(1): 29-38

4.3 The role of internalizing prophetic values in generating teachers' competences to create more effective teaching and learning activities.

4.3.1 Building of Teachers' Values

The first program of internalizing of prophetical values in generating teachers competences is to build teachers values. This purpose is to ensure that all elements of competences are understood by teachers as parts of prophetical values, especially those elements represent Al-Qur'an and Al-Hadith. Below is the list of teachers' understanding for strong correlation between academic teachers' competences and prophetical values:

Table 7: Academic Competences in Teachers' Prophetic Perception

\begin{tabular}{|l|l|l|l|}
\hline No. & Competences & Internalization Prophetical Values & $\begin{array}{l}\text { Percentage of } \\
\text { Understanding }\end{array}$ \\
\hline 1. & $\begin{array}{l}\text { Pedagogical } \\
\text { Competences }\end{array}$ & $\begin{array}{l}\text { The first revelation that Allah revealed to Muhammad was } \\
\text { about pedagogy (Al-Qur'an) }\end{array}$ & $100 \%$ \\
\hline 2. & $\begin{array}{l}\text { Personal } \\
\text { Competences }\end{array}$ & $\begin{array}{l}\text { Everyone will be held accountable according to their capacity } \\
\text { (Al-Hadith) }\end{array}$ & $100 \%$ \\
\hline 3. & $\begin{array}{l}\text { Social } \\
\text { Competences }\end{array}$ & $\begin{array}{l}\text { Everyone is asked to socialize inclusively based on the value } \\
\text { of piety (Al-Qur'an) }\end{array}$ & $100 \%$ \\
\hline 4. & $\begin{array}{l}\text { Professional } \\
\text { Competencies }\end{array}$ & $\begin{array}{l}\text { Knowledgeable believers have freedom and confidence in the } \\
\text { assembly environment with higher degrees (Al-Qur'an) }\end{array}$ & $100 \%$ \\
\hline Average & All Competences & $\begin{array}{l}\text { All teachers fully understand that academically teachers' } \\
\text { competences have strong correlation with prophetical values }\end{array}$ & $100 \%$ \\
\hline
\end{tabular}

\subsubsection{Creating of Practical Values}

The second program of internalizing of prophetical values in generating teachers competences is to create the value of quality practice. This purpose is to ensure that all elements of competences as parts of prophetical values which represent Al-Qur'an and AlHadith are implemented to produce effectively learning and teaching activities. Following below is the list of practical values as implementation of teachers' values:

Table 8: Teaching and Learning Activies as Practical Values

\begin{tabular}{|l|l|l|l|}
\hline No. & Activity & How to do it & Why to do it \\
\hline 1. & Praying & $\begin{array}{l}\text { Praying before and after learning an teaching } \\
\text { activities led by the class leader and monitor } \\
\text { by teacher }\end{array}$ & $\begin{array}{l}\text { Pedagocically bring students to special } \\
\text { situations and focus on starting the } \\
\text { lessons }\end{array}$ \\
\hline 2. & Muraja'ah & $\begin{array}{l}\text { Memorizing and understand the verses of Al- } \\
\text { Qur'an }\end{array}$ & $\begin{array}{l}\text { To memorize the values of religious } \\
\text { teachings so students know more about } \\
\text { God's commands and prohibitions }\end{array}$ \\
\hline 3. & $\begin{array}{l}\text { Memorizing } \\
\text { prayers for daily } \\
\text { life activities }\end{array}$ & $\begin{array}{l}\text { Everyone is asked to memorize and to } \\
\text { understand Al-Qur'an by firstly reading } \\
\text { together and later on one by one }\end{array}$ & $\begin{array}{l}\text { To equip students with standard } \\
\text { praying to start and to end of any } \\
\text { activities by the name of God }\end{array}$ \\
\hline 4. & $\begin{array}{l}\text { Muhadharah } \\
\text { Teacher to schedule each student to be at the } \\
\text { front of the class to practice public speaking } \\
\text { practice with the content based on Islamic } \\
\text { teachings }\end{array}$ & $\begin{array}{l}\text { To build students' self confidences, } \\
\text { articulation drill and to memorize and } \\
\text { understand Islamic teachings }\end{array}$ \\
\hline 5. & Dhuha Prayer & $\begin{array}{l}\text { Perform by students when the sun begins to } \\
\text { rise approximately 7 cubits from sunrise to } \\
\text { noon time. }\end{array}$ & $\begin{array}{l}\text { To get sunnah reward and to be } \\
\text { optimistic to get Allah's blessing from } \\
\text { learning and teaching activity }\end{array}$ \\
\hline 6. & Dhuhr Prayer & $\begin{array}{l}\text { One of obligatory prayers 5 times and } \\
\text { perform by students after the sun has slipped } \\
\text { until late in the afternoon }\end{array}$ & $\begin{array}{l}\text { To educate in carrying out the } \\
\text { prophetical obligations and create } \\
\text { universal values }\end{array}$ \\
\hline
\end{tabular}

\subsubsection{Maximizing of Results Values}

The roles of internalization the prophetical values in generating teachers competences by building teachers' values and creating practical values had produced an integrated results. Those results were actually the optimum efforts of the teachers in managing the classroom effectively. Those teachers' performances became madrasa's performances. The performances of madrasa represented by generating of students in yearly basis and also by increasing madrasa rank in the national examination at the provincial level for the special are of the capital, called Provinsi DKI Jakarta. Below are the table of madrasa's performances which displayed for 5 years figures and started from 2017 until 2021: 
Suprihatini et al; Saudi J. Humanities Soc Sci, Jan, 2022; 7(1): 29-38

Table 9: Five Years Madrasa's Performance in Term of Total Students

\begin{tabular}{|l|l|l|l|}
\hline No. & New School Academic & $\begin{array}{l}\text { Total of New } \\
\text { Students }\end{array}$ & Remarks \\
\hline 1. & $\begin{array}{l}\text { New School Academic Year } \\
2017 / 2018\end{array}$ & 400 & $\begin{array}{l}\text { This year, total 400 new students are used as the initial } \\
\text { number of calculations within span of 5 years }\end{array}$ \\
\hline 2. & $\begin{array}{l}\text { New School Academic Year } \\
2018 / 2019\end{array}$ & 449 & $\begin{array}{l}\text { This year, the increase in the number of new students is } 49 \\
\text { people, by 12.25\% }\end{array}$ \\
\hline 3. & $\begin{array}{l}\text { New School Academic Year } \\
2019 / 2020\end{array}$ & 445 & $\begin{array}{l}\text { This year, the increase in the number of new students is } 45 \\
\text { people, by 11.25\%. }\end{array}$ \\
\hline 4. & $\begin{array}{l}\text { New School Academic Year } \\
2020 / 2021\end{array}$ & 404 & $\begin{array}{l}\text { This year, the increase in the number of new students is } \\
\text { only 4 people, by 1\%. A small increase in the number, } \\
\text { caused by the covid-19 pandemic. }\end{array}$ \\
\hline 5. & $\begin{array}{l}\text { New School Academic Year } \\
2021 / 2022\end{array}$ & 411 & $\begin{array}{l}\text { This year, the increase in the number of new students is } \\
\text { only 11 people, by 2.75\%. Higher than previous year as the } \\
\text { impact of the pandemic decreased. }\end{array}$ \\
\hline
\end{tabular}

Source: Formal Document of Madrasah Tsanawiyah Miftahul Umam - October 2021

In the context of the output quality of graduates, the table below represents the achievements of Madrasa Miftahul Umam in a time span of 4 years. Starting from 2017/2018 academic year until 2020/2021 academic year. In the two years there has been no graduate quality rating due to the covid-19 pandemic. Below is a list of graduate quality achievements rankings:

Table 10: Quality Achievement of Madrasa Miftahul Umam at Private Madrasa in DKI Jakarta Province

\begin{tabular}{|l|l|l|l|l|}
\hline No. & Academic Year & Capaian Nilai Rerata & Peringkat & Catatan \\
\hline 1. & Academic Year 2017/2018 & 48,23 & 27 & \\
\hline 2. & Academic Year 2018/2019 & 52,65 & 16 & \\
\hline 3. & Academic Year 2019/2020 & & & No national exam due to pandemic \\
\hline 4. & Academic Year 2020/2021 & & & No national exam due to pandemic \\
\hline
\end{tabular}

Source: South Jakarta Ministry of Religion - document 2021

\section{DISCUSSION}

\subsection{Madrasa Management Role in generating} Teachers' Competences Through Visions and Missions

From the findings, the vision of the foundation and madrasa have emphasized points that basically have something in common, namely creating quality graduates who are qualified in aspects of faith and piety and mastering science and technology. Thus, both of them in principle have goals on national education, under Law of the Republic of Indonesia Number 20 of 2003 Concerning the National Education System, ChapterI, Article 1, Paragraph 1, namely efforts to realize and develop the potential of students, to have spiritual strength, noble character, personality and skills needed for themselves, society, nation and state. Then the existence of a vision on the foundation and madrasa Miftahul Umam is proven that as an organization, it requires a basic operational foundation. Because effective organizational goals can only be achieved through a vision. As Surangan said, vision is an outline of the concept of an organizations's strategic plan that must be implemented. And the effectiveness of the strategy, the management of the organization, begins with projecting its vision (J.M. Suranga, 2014: 34-35). Besides that, the vision is made concisely, clearly, maintains the noble values of religious teachings as a counterwheight, and describe the organization goals for future success oriented to the mastery of science and technology. According to Avery et al, the important characteristics of a vision are challenge, future orientation, clarity, abstractness and stability (Sooksan Kantabutra et al., 2010: 39).

Meanwhile, almost all the points of mission point to implementation of madrasa-based management practices. Madrasa leadership is required to implement a general management functions. There is no specific point where mission contents about achievement of generationg teachers' competences. Whereas, only teachers who are able to develop students morale so that influence students in achieving goals for both intellectual and behavioral (Nurlela Sari, 2013: 161). It means, the teachers are only leading posision to play vital role in actuating vision and mission of foundation and madrasa. Another word, projection of vision and mission has to be done by a competence team. As mentioned by Gofur Ahmad, mostly the member of a team in designing the vision and mission have only insufficient theoretical understanding in making a formula (Gofur Ahmad, 2012: 2). Thus, the results of the research above explain that the vision and mission of foundation and madrasa have not touched the operational elements of the goals that is to generate teachers's competences. According to Reza and Rukanto (2017), the authority of qualified educational institution should be responsive to the demands of changes that occur in their evinroment. Therefore, in 
Suprihatini et al; Saudi J. Humanities Soc Sci, Jan, 2022; 7(1): 29-38

order the policies meet with operational needs of educations, institution must be built on a standardized organization culture, so that institution is able to have strengths in implementing a quality educational process. Many research results indicate that the implementation of a healthy vision and organizational culture on an ongoing basis, is able to improve the quality of education (Reza Aulia Akbar et al., 2017: 127).

The relatively unresolved obstacles, because they are related to the interests and policies of the authorities of educational institution. This obstacles can put the teachers in a situation of confusion and even become ignorant and demotivated. This attitude of the teachers have impact on the quality of their performances. The teachers that are expected to be able to realize the vision and mission by creating students who are in accordance to the vision and mission, become helpless and psychologically feel frustrated. In their research, Khan et al found that teachers who are frustrated and stressed are caused by their reaction to factors in their environment that are not in accordance with their performance, whether related to assignments or other problems. Teachers who are stressed and frustrated can negatively impact teachers' performances and become unproductive. And this detrimental to teachers personally, students and of course to the institutions. Therefore, educational institutions must focus on the problem of teachers and provide adequate support so that teachers are able to manage the problems they face (Anwar Khan et al., 2012: 21).

\subsection{Teachers Role in facing the obstacles and motivating themselves to generate the competences}

The unsynchronized coordination between the foundation and its fostered madrasa is a common phenomenon. It does not just happen in Miftahul Umam foundation and madrasa. According to Suryarama, although the Republic of Indonesia Law Number 28 of 2004 concerning foundation had been issued, the operational behavior of foundation, so far, has only been based on habits in society, where the founders, administrators and supervisors of foundation, especially family, the foundation is not only as a forum for development of social, religious and humanitarian activities, but there are other purposes. The main problem seen is that the foundation management caused by administrative management problems around $40 \%$, financial problems around $20 \%$ and other problems around 40\% (Suryarama, 2009: 55). In this study, the inappropriateness of policies and operations of institution can be seen in table-4. The Impact is not only for madrasa, especially for the decline of teachers' performance caused by demotivation, ignorant and possibly stress in dealing with situations and with woks.

What happened at the research site was relatively the same as Suryarama said, where the teachers' competences level of academic-based was relatively low. In table-5 can be seen that the average quality of teachers' competences is at level of $66.25 \%$. This is because according to Khan et al, teachers who are stressed cannot work well. Enjoyment of work and motivation decreases and sometimes shows unwanted behavior such as lazy to work and make a lot of mistakes. The implication is the the level of students satisfaction also decreases because teachers are not able to carry out the quality of learning activities. As a result, many parents or guardians of students complain and even protest. Thus, the picture of whole madrasa is damaged. Therefore, madrasa management should have general awareness regarding efforts to deal with teachers' stress by helping them to have competence in dealing with stress and at the same time improving their performances. And vise versa with the teachers. They need to have competence in dealing with stress and to have willingness to work hard to generate their performances (Anwar Khan et al., 2012: 26).

Based on Khan's statement concerning research findings, both solution concepts also hapenned at Madrasah Miftahul Umam. Madrasa management give policy where teachers have own choices of having outside programs to generate competences. This policy is expected to create a conducive situation for the theachers, as well as reducing the teachers' discomfort in carrying out the perceived duties. The outside programs that taken by teachers to generate their own competences can be seen in table- 6 . The choices given by madrasa management to the teachers is also intended to create teachers' self-awareness to develop. This selfawareness is the teachers' strength and never give up. So that whatever obstacles they face are always used as challenges as well as practice to be patient in facing obstacles. Patience in the face of obstacles is a form of emotional intelligence. So the implication is that teachers can work with self-efficacy. This is parallel with what Susnaini et al said in their research which found the facts that: (1) emotional intelligence has a direct positive effect on teachers's performances with and effect of $15.45 \%$; (2) self-strength has a direct positive effect on teachers' performance by $10.45 \%$ and teachers's emotional intelligence has a direct positive effect on self-strength by $9.85 \%$ (Susnaini Julita, 2019: 33).

\subsection{The role of internalizing prophetic values in generating teachers' competences to create more effective teaching and learning activities.}

To find solutions to various obstacles faced by madrasa and its work environment, especially by teachers so that they are not able to work optimally, madrasa create teaching programs to generate teachers' competences as well as understanding and practicing religious learning practices. This is considered to be part of the solution and moreover, teachers understand that academic-based competences is an inseparable part of prophetic values (see table-7). This is because 
Suprihatini et al; Saudi J. Humanities Soc Sci, Jan, 2022; 7(1): 29-38

religion is considered capable of creating a harmonious and conducive atmosphere. The values of religious teachings have the power to motivate teachers to continue to work optimally even though they are faced with various obstacles. According to Kumar, religious belief by practicing religious teachings has long been connected in curing several mental illnesses such as hysteria, neurosis and psychotic delusions. This is because regious beliefs and practices of worship can provide a source of strength to create comfort, hope and realize a meaningful role of life activities (Vikas Kumar, 2018: 68).

Madrasah programs in coaching teachers to be able to manage the religious-based learning processs can be seen in table- 8 . In this programs, madrasa management seeks two maintain two things, namely maintaining religious education activities as a feature of madrasa, and making this program an increase in teachers' competences. Religion-based learning activities have a positive psychological impact on teachers as religion affects the attitude and behavior of people or mechanism that work within a person. Because the way of person thinks, behaves and reacts cannot be separated from the beliefs, and those beliefs become personal strengths (Firdaus, 2014: 19). However, beside madrasa that supports in generating teachers competences, he teachers are also expected to improve themselves so that their academic competences are strengthened by the concepts of undertstanding and practicing religious worship skills. According to Bolotio, that the understanding of religion by teachers has a direct positive effect on teachers' performance. Increasing teachers' competences by renewing religious knowledge, can increase faith and piety to Allah, as well as increase self awareness that faith and piety are a necessity (Rivai Bolotio, 2017: 34).

The discussion above proves that the programs in generating of prophetic-based teachers' competences run by madrasa - through internalization of religious understanding followed by religious practices have an impact on improving performance, because teachers are able to do better in doing the jobs. In accordance of Mawdudi's opinion, that prophetic values have dogmatic power that can influence teachers to be more perfectly persons (Fridayanti, 2015: 2017). Mawdudi's opinion was strengthened by Hamali that a person's religious counciosness as a reflection of faith in Allah and is able to form noble character and high social awareness (Syaiful Hamali, 2017: 73). In other words, internalizing prophetic values towards generating teachers' competences capable of producing teachers' behavior, creating an effective learning process and resulting in quality of education outcomes.

The improvement of education at madrasa Miftahul Umam is evidenced by relatively continuous increase in the number of new students every year.
Increasing new students every year can be seen in table9. In addtition, there is also an increase in the ranking quality of graduates. Increasing of ranking can be seen in table-10. The improvement of those two elements above proves that as stated by Shofwatun et al., teachers' performances which are in optimum level and they have their academic and prophetic competences are considered as good aspects of teachers which are able to influence on the academic achievement of students (Shofwatun Amaliyah et al, 2017: 28).

\section{CONCLUSION}

The vision and mission of the foundation as well as madrasa Miftahul Umam have projections that are in accordance with the goals of the national education system. However, the management of the visions and the missions is still not able to become the core tool that is used as the basic of madrasa operasionalization. The contents are too general, no time-limited of achievement, not socialized, not proper applied and not controlled in the result of outcomes. Those mismanagements are evidenced by several obstacles caused by various aspects where madrasa has not been able to produce maximum contributions in generating teachers' competences academically. That condition implicates the teachers that have not been able to organize effective teaching and learning activities.

However, to contribute towards generating teachers' competences, madrasa Miftahul Umam issues policy where teachers have freedom to choose the programs to improve their academic competences ouside of madrasa. This freedom provides understanding fo teachers to have their own motivations. The contibution of madra Miftahul Umam to teachers is also carried out in different formats is considered the best solution in certain condition. Madrasa create prophetic-based teaching which implicate to the teachers to increase religious knowledge as well as understand how academic competences are seen from prophetic perspective. So that the teaching task of the teachers is understood not only as carrying out the academic obligations but also as a prophetic obligation that must be carried out with sincerity. In the end, it is able to create better quality of graduates. So, the internalization of prophetic values can generate teachers' competences.

\section{REFERENCES}

- Ahmad, G. (2012). TALU Management: BusinessEnvironment Engineering. Jakarta: PT Gramedia Widiasarana Indonesia.

- Akbar, R. A., \& Rukanto. (2017). The Effect of Implementing the Vision and Organizational Culture in Education on the Quality of Education. Jurnal Manajemen, Kepemimpinan, dan Supervisi Pendidikan, 2(1). 
Suprihatini et al; Saudi J. Humanities Soc Sci, Jan, 2022; 7(1): 29-38

- $\quad$ Amaliyah, S., Khairul, A., \& Fathul, L. N. (2017). The Effect of Religious Identity toward Academic Performance: An Experimental Study. Proceeding of 6th Annual International Conference on Cognitive and Behavioral Psychology of Department of Psychology State Islamic University of Maulana Malik Ibrahim Malang Malang, Indonesia, ISSN 2251-1865 doi: 10.5176/22511865 CBP17.6.

- Andriani, D. E. (2012). Need-Based Program of Teacher Quality Improvement", Jurnal Manajemen Pendidikan, 23(5).

- Anshori, A. H. (2016). The Important of MadrasaBased Management in Effective Madrasa Leadership. Jurnal Tarbawi STAISMAN Pandeglang, 2(1).

- Bolotio, R. (2017). The Influence of Religious Understanding on the Performance of Madrasah Ibtidaiyah Teachers in Manado. Journal of Islamic Education Policy, 2(1).

- Dunlosky, J., Katherine, A. L., Elizabeth, J. M., Mitchell, J. N., \& Daniel, T. W. (2013). Improving Students' Learning with Effective Learning Techniques: Promising Directions from Cognitive and Educatational Psychology. Journal of Psychological Science in the Public Interest, 14(1).

- Firdaus. (2014). The Urgency of Religious Psychology, in Family, School and Community Education. Jurnal Al-AdYaN, IX(2).

- Fridayanti. (2015). Religiosity, Sprituality, in the Study of Psychologi and urgency of the formulation of Islamic Religiosity. Psymphatic Jurnal Ilmiah Psikologi, 2(2).

- Hadi, A. (2013). The Concept of SWOT Analysis SWOT in Improving the Quality of Madrasa Institution. Jurnal Ilmiah Didaktika IAIN ArRaniry, XIV(1).

- Hamali, S. (2012). The Existence of the psychology of Religion in the Development of Islamic Society. Jurnal TAPIs, 8(1).

- Ibrahim. (2015). Implementation of School-Based Management at SDN Sakti Pidie. Jurnal Administrasi Pendidikan Pascasarjana Universitas Syiah Kuala, 3(1).

- Julita, S., Dewi, H., \& Sandra, A. G. (2019). The Influence of Emotional Intelligence and SelfEfficacy on the Performance of Mathematics Teachers. JUPITEK - Jurnal Pendidikan Matematika, 2(1).

- Kantabutra, S., \& Gayle, C. A. (2010). The power of vision: statements that resonate. Journal of Business Strategy, 31(1).
- $\quad$ Khan, A., Ishak Mad, S., Sadaf, K., \& Shafiq, G. (2012). Teachers' Stress, Performance \& Resources The Moderating Effects of Resources on Stress \&Performance. International Review of Social Sciences and Humanities, 2(2).

- Kumar, V. (2018). Role of Religion and Spirituality in Mental Health: A Review. Phonix International Journal for Psychology and Social Sciences (PIJPS), PIJPS ISSN No. 2456 - 5180 (Online).

- Ma'ruf, M. (2015). The Concept of Educational Management in Al-Qur'an and Al-Hadits. Journal of Didaktika Religia, 3(2).

- Mainuddin. (2017). Teacher Competence in the Perspective of Islamic Education", Jurnal Pendidikan Islam Al-Munawwarah, 9(2).

- Nata, Abuddin. (2014), Sociology of Islamic Education. Jakarta: RajaGrapindo Persada.

- $\quad$ Nur, M., Cut, Z. H., \& Sakdiah, I. (2016). School Management in Improving the Quality of Education at SDN Dayah Guci Pidie District. Jurnal Administrasi Pendidikan Pascasarjana Universitas Syiah Kuala, 4(1).

- Ridwan, M. K., Adang, K., \& Muhammad, M. (2016). Religion: Between Love and Criticism. Fikrah: Jurnal Ilmu Aqidah dan Studi Keagamaan, 4(2).

- Saefullah, A. (2008). The Role of Religion in Overcoming Frustration and Depression Problems: a Study of Psychology. Journal of Dakwah dan Komunikasi STAIN Purwokerto, 2(2).

- Samrin. (2015). Islamic Education in the Indonesian National Education. Jurnal Al-Ta'dib, 8(1).

- $\quad$ Sari, N. (2013). The Importance of Teaching Moral Values to The Students. Journal of English and Education, 1(1).

- Sujana, I Wayan Cong. (2019). The Function and Objective of Indonesian Education. ADI WIDYA: Jurnal Pendidikan Dasar, 4(1).

- Suranga, J. M. (2014). Importance of Corporate Vision. Proceedings of the HR Conference, 1(1).

- Suryarama. (2009). The Role of Foundation in the Management of Education in Private University. Jurnal Organisasi dan Manajemen, 5(1).

- Syah, D., Supardi, A. N., \& Abdul, A. H. (2006). The Planning of Teaching System in Islamic Education. Jakarta: Faza Media.

- Uwes, S., \& Rusdiana. (2017). The Thinking System of Educational Management: an Alternative to Educational Problem Solving. Bandung: Pustaka Setia. 